\title{
INFLUENCE OF LONGITUDINAL MAGNETIC FIELD IN THE MPC CHANNEL ON THE DENSITY OF GENERATED PLASMA STREAM
}

\author{
A.K. Marchenko ${ }^{1}$, O.V. Byrka ${ }^{1}$, V.A. Makhlai ${ }^{1,3}$, S.S. Herashenko ${ }^{1,3}$, \\ D.G. Solyakov ${ }^{1,3}$, Y.E. Volkova ${ }^{1,3}$, D.V. Yeliseyev ${ }^{1}$, K. Novakowska-Langier ${ }^{2}$ \\ ${ }^{1}$ Institute of Plasma Physics, National Science Center "Kharkov Institute of Physics and \\ Technology", Kharkiv, Ukraine; \\ ${ }^{2}$ National Centre for Nuclear Research (NCBJ), Otwock-Świerk, Poland; \\ ${ }^{3}$ V.N. Karazin Kharkiv National University, Kharkiv, Ukraine \\ E-mail:marchenkoak@kipt.kharkov.ua
}

The paper is devoted to experimental measurements and analysis of parameters of the plasma streams generated by magnetoplasma compressor (MPC) upgraded with an external axial magnetic field. Influence of the external axial magnetic field of $0.24 \mathrm{~T}$ on helium plasma streams $(\mathrm{P}=2 \mathrm{Torr})$ has been studied. The measurements of average electron density distributions were performedboth with and without an external axial B-field. Distributions of plasma electron density $\mathrm{N}_{\mathrm{e}}(\mathrm{L})$ were measured with spectroscopy in the plasma stream and in the compression zone using Stark broadening of He I and He II spectral lines. Plasma-surface interaction processes were also analyzed.

PACS: 52.40.Hf; 52.70

\section{INTRODUCTION}

Magnetized plasma streams are of particular interest for basic plasma dynamics research and also for various technological applications, such as prospective sources of high energy beams and radiation in wide wavelengths [1], testing of fusion reactor materials with high energy loads [2-4], surface modification and improvement of material properties [5-7].

Optimization of operation modes of plasma device for providing effective variation of plasma parameters is an important aspect in plasma technologies, fusion science and engineering. For instance, experimental regimes of MPC plasma facility operation define theproperties of generated dense plasma flows of different ions with the ability of effectively varying the specific energy loads at plasma exposure of materials $[8,9]$.

MPC has been studied in our laboratory since 2007 operating in various working modes and using different working gases [10-12]. Now it has been upgraded with additional external magnetic field with the aim to increase the plasma parameters that requires higher discharge current. According to available numerical simulations, the external magnetic field should help to overcome the effect of the "current crisis" [13].

Our first experimental studies of the MPC operation with external axial magnetic field were described in [14]. Particular attention was paid to the measurements of the electric field, the discharge current, and the potential distribution changes.

In this paper, we report our experimental results on the influence of additional magnetic field on the plasma density behavior in compressed plasma stream and also in front of the target surface during the plasma-surface interaction.

\section{EXPERIMENTAL SETUP AND DIAGNOSTICS}

The MPC upgraded with a magnetic coil that has been installed in the accelerating channelis shown in Fig. 1.

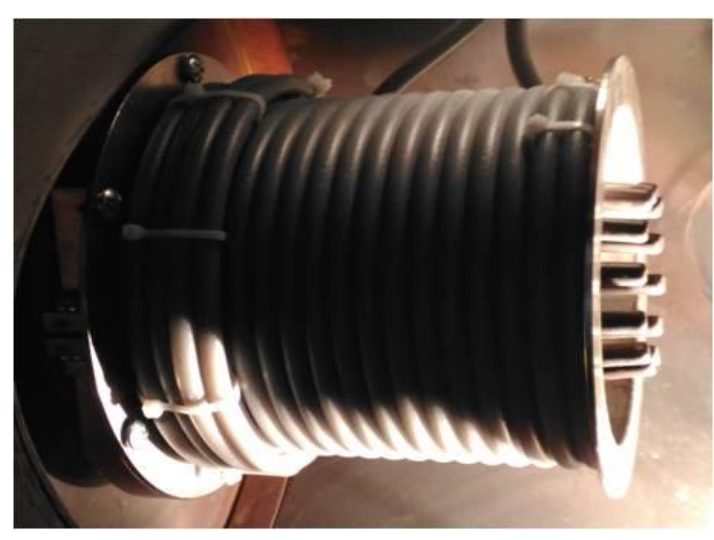

Fig. 1. MPC accelerating channel with installed solenoid

The length of the magnetic coil is $17 \mathrm{~cm}$, and the inner diameter is $15 \mathrm{~cm}$. This coil is supplied from acapacitor bank with a total capacitance of $700 \mu \mathrm{F}$. It can provide inside the MPC channel an axial magnetic field up to $0.4 \mathrm{~T}$ that decreases two fold at the channel outlet. Fig. 2 illustrates the distribution of axial magnetic field $\mathrm{B}_{\mathrm{z}}$ inside the MPC accelerating channel.

The MPC is installed in the 2-meter long vacuum chamber with diameter of $40 \mathrm{~cm}$. The MPC discharge is supplied by a capacitor bankwith a stored energy of $28 \mathrm{~kJ}$ (at $25 \mathrm{kV}$ ).

For measurements of the plasma streams parameters complex of optical diagnostic consisting of diffractional spectrometer DFS-452 and monochromator MDR-23 
was in use. These measurements are integrated along the observation chord as well as over discharge time. Piezo-detectors, bolometers, local copper calorimeters, electrical and magnetic probes have been also used in addition to spectroscopy for plasma parameters measurements.

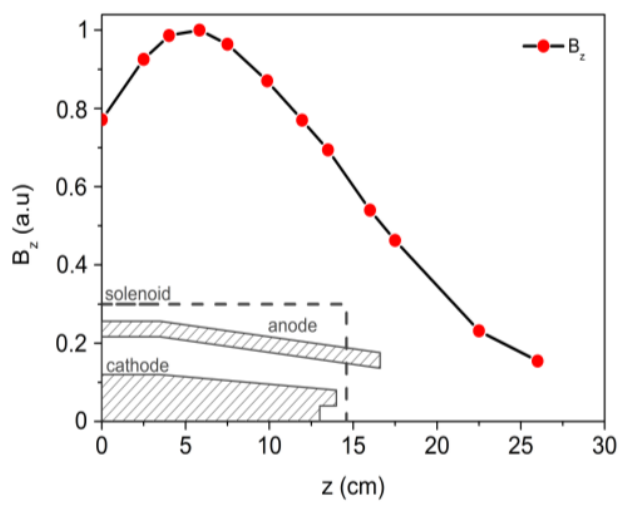

Fig. 2. Distribution of axial magnetic field $B_{z}$ inside the MPC accelerating channel

\section{DISTRIBUTIONS OF PLASMA ELECTRON DENSITY IN MPC WITH AN EXTERNAL MAGNETIC FIELD AND WITHOUT IT}

During these experiments the capacitor bank was charged up to $20 \mathrm{kV}$. The maximum value of the discharge current acieved $400 \mathrm{kA}$ with a half period of $10 \mu \mathrm{s}$. Helium chosen as the working gas, the vacuum chamber was filled by Heunder residual pressure of 2 Torr. This operation mode was analyzed earlier in [11, 12]. Measurements were performed either with external magnetic field $(B=0.24 \mathrm{~T})$ or without it $(\mathrm{B}=0 \mathrm{~T})$.

The analysis of the Stark-broadening spectral lines is one of the widely used plasma diagnostics techniques, especially formonitoring of the plasma electron density [15]. Distributions of plasma electron density $\mathrm{N}_{\mathrm{e}}$ (L) were obtained in the plasma stream and, in particular, in compression zone using Stark broadening of He I and He II spectral lines after the procedure of instrumental broadening exception $\left(\Delta \lambda_{i}=0.2 \AA\right)$. Fig. 3 shows the comparison of experimental and theoretical shapes of the He II (4685 $\AA$ ) and He I (4471 $\AA$ ) spectral lines. Presumably spectral lines of different ionization stages characterize different parts of plasma stream, so analysis of both contours provides more complete data about plasma density $[15,16]$. It must be pointed out that the fitting result includes only the purely Lorentz component of the spectral lines contour, excluding Gaussian one. It is easy to see that the experimental and theoretical data have a good agreement. It can indicate thatour experimental conditions correspond to the local thermodynamic equilibrium.

To determine the effect of the additional magnetic field on the evolution and magnitude of the plasma electron density, experimentally obtained half-width values of the working gas spectral lines were used to acquire the spatial distributions of $\mathrm{N}_{\mathrm{e}}$ in MPC plasma stream both with and without B-field. Fig. 4 shows that for the He I spectral line (4471 $\AA$ ), which characterizes the neutrals in plasma, there are no changes in the value and behavior of the $\mathrm{N}_{\mathrm{e}}$. In this case the density near the electrodes $(\mathrm{L}=0 \mathrm{~cm})$ and at the distance of $10 \mathrm{~cm}$ from them are equal $-\mathrm{N}_{\mathrm{e}}=1.5 \cdot 10^{16} \mathrm{~cm}^{-3}$, and only at $\mathrm{L}=4 \ldots 6 \mathrm{~cm}$ electron density is twice higher.
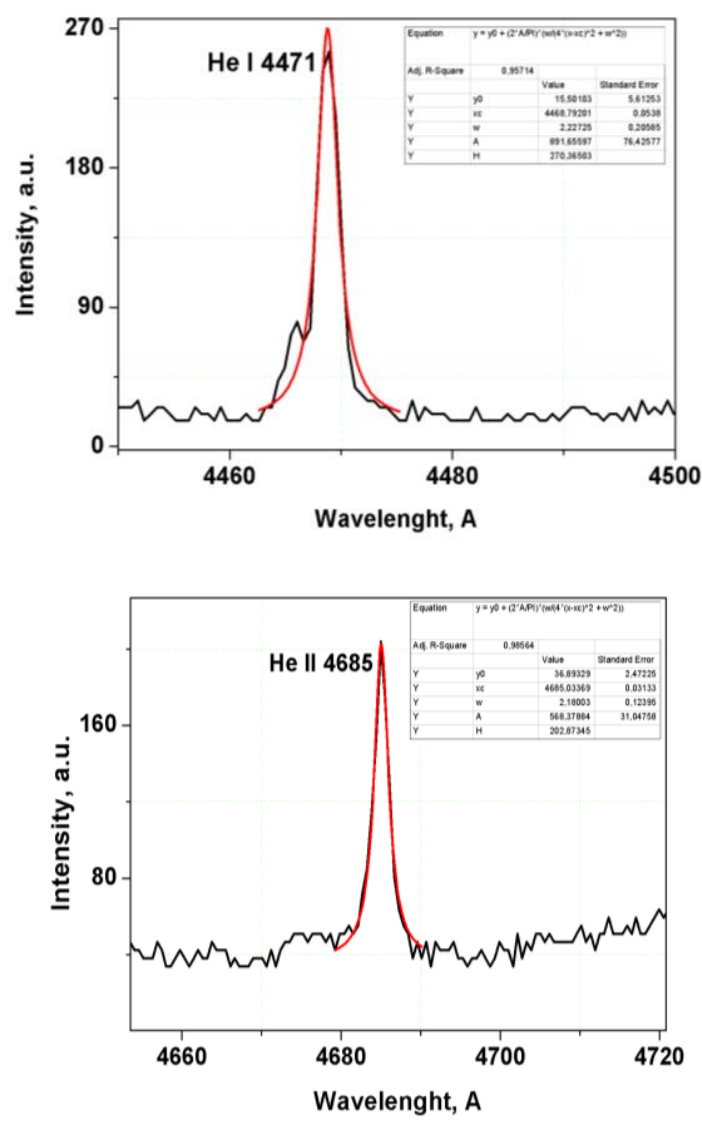

Fig. 3. Typical wave forms and fitting results (Lorentz component) of He I (4471 A) (a) and He II $(4685 \AA)(b)$ in plasma stream with $B=0.24$

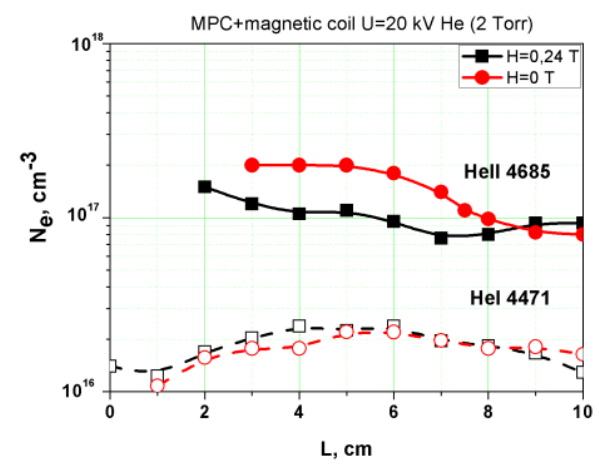

Fig. 4. Spatial distributions of plasma electron density $N_{e}(L)$ in MPC with axial magnetic field $B=0.24 T$ and $B=0$

In absence of an external magnetic field, the behavior of the electron density evaluated from the He II (4685 $\AA$ ), which characterizes the dynamics of single ionized helium atoms, significantly differs from the $\mathrm{N}_{\mathrm{e}}$ (L) when an additional magnetic field is turned on. Namely, the value of $\mathrm{N}_{\mathrm{e}}=2 \cdot 10^{17} \mathrm{~cm}^{-3}$ at $\mathrm{B}=0 \mathrm{~T}$ exceeds twice the density with a magnetic field $\mathrm{B}=0.24 \mathrm{~T}-\mathrm{N}_{\mathrm{e}}=1 \cdot 10^{17} \mathrm{~cm}^{-3}$ for distances up to $6 \mathrm{~cm}$ from electrodes. But further, sharp decrease to $\mathrm{N}_{\mathrm{e}}=0.85 \cdot 10^{17} \mathrm{~cm}^{-3}$ occursat the distances of 6 to $9 \mathrm{~cm}$ from the electrode system of MPC. This can be explained by the fact that ions of different ionization 
stages characterize different spatial layers of the plasma stream. Thus, the analysis of the electron density distributions showed that an external magnetic field in the MPC channel is not affecting the averagedensity of helium neutrals. However, the density of single charged ions, which are more sensitive to the influence of the magnetic field, increased twice.

\section{$\mathrm{N}_{\mathrm{E}}$ BEHAVIOR DURING PLASMA- SURFACE INTERACTION}

Studies of plasma-surface interaction were carried out using stainless steel target with a diameter of $2 \mathrm{~cm}$ that was located at the distance of $6.5 \mathrm{~cm}$ from the outer electrode of MPC. Measurements of electron density distributions near exposed surface were performed on the base of emission spectra of the plasma stream interacted with target. Results for MPC regimeswith external magnetic field are presented in Fig. 5.
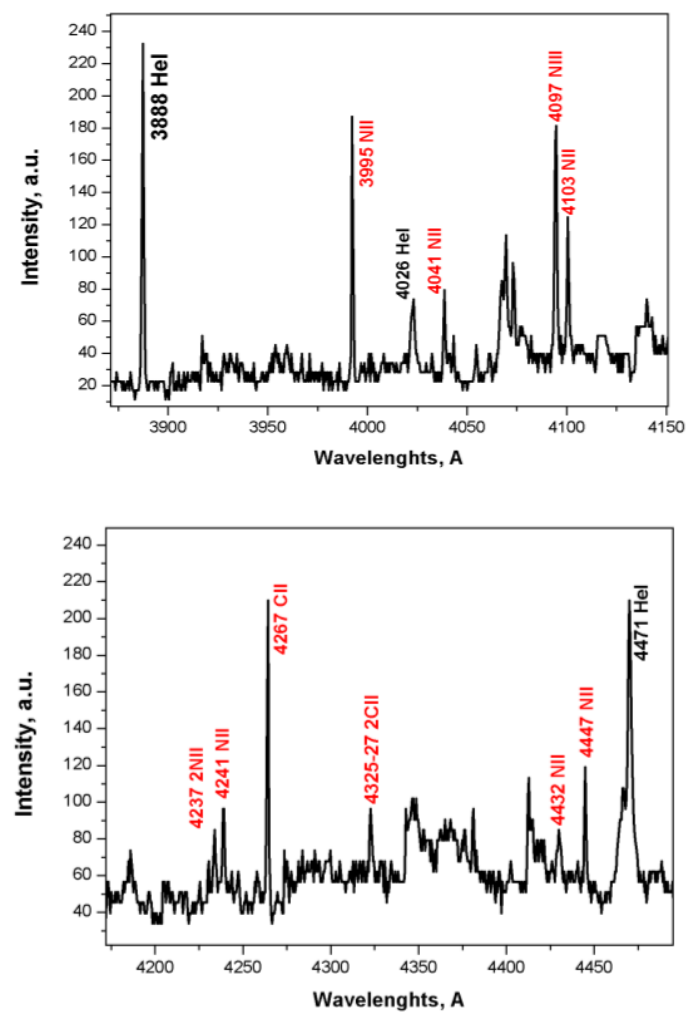

Fig. 5. Different parts of emission spectra $3875 \ldots 4150 \AA$ (a) and $4175 \ldots 4500 \AA$ (b) of plasma stream near the steel target in the presence of an external magnetic field $B=0.24 T$

Analysis of plasma radiation spectra showed that in addition to the spectral lines of the working gas He I (3888; 4026; $4471 \AA)$ and He II $(4685 \AA)$ a number of impurity spectral lines - N II (3995; 4041; 4237; 4432; $4447 \AA)$, C II (4267; $4325 \AA$ ), N III (4097; $4103 \AA)$ have been identified. It should be noted that nitrogen was selected as a small diagnostic dope for more precise measurements whilecarbon is appeared as a result of sputtering of target material.

Fig. 6 shows comparison of $\mathrm{N}_{\mathrm{e}}$ spatial distributions in a free plasma stream and near the steel target exposed by the plasma in regimes with magnetic field $\mathrm{B}=0.24 \mathrm{~T}$ (a) and without it (b) accordingly. The electron density dynamics, as determined from $\mathrm{He}$ spectral lines profiles, remains almost the same $\left((1.5 \ldots .2) \cdot 10^{17} \mathrm{~cm}^{-3}\right)$ until $\mathrm{L}=5 \mathrm{~cm}$, where the influence of target becomes noticeable and the electron density increases twice.

But $\mathrm{N}_{\mathrm{e}}$ value determined from the impurity spectral lines (N II) is higher because it corresponds to the central part of plasma stream, in contrast to one evaluated from helium, which is attributed to the periphery.
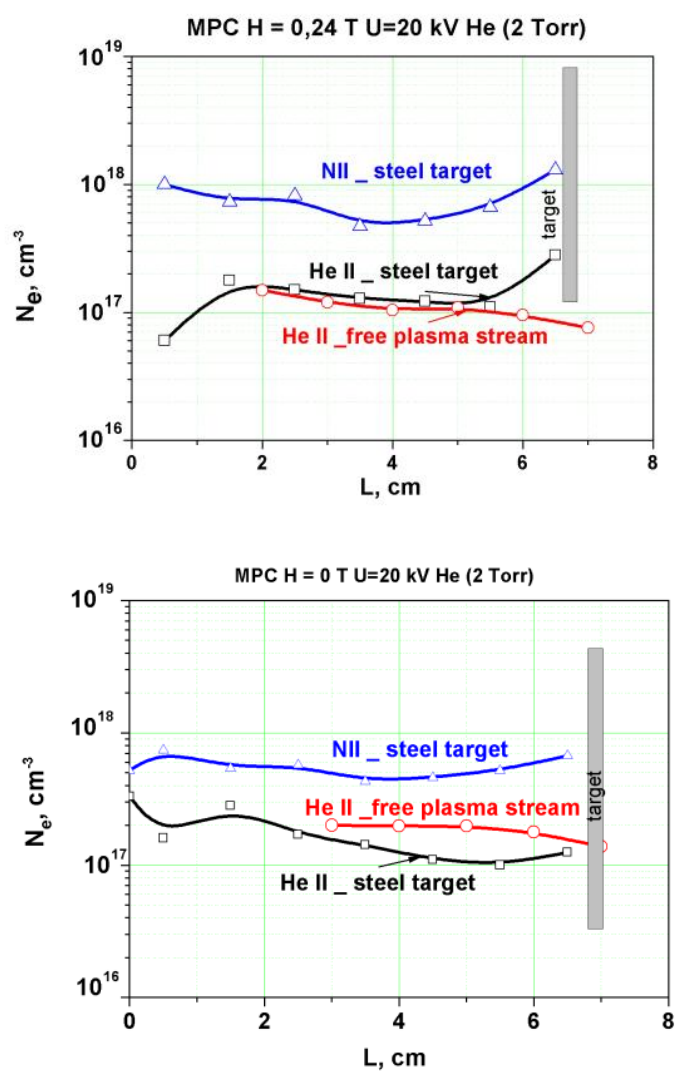

Fig. 6. Spatial distributions of plasma electron density near the stainless steel target and in a free plasma stream in MPC in the presence of an external magnetic field $B=0.24 T(a)$ and $B=0 T(b)$

At the distance of $3 \mathrm{~cm}$ from the electrodes, where effect of the target presence is not yet appreciable, there is a slight decrease from 8 to $5 \cdot 10^{17} \mathrm{~cm}^{-3}$. $\mathrm{N}_{\mathrm{e}}$ that estimated from N II spectral lines is about $1 \cdot 10^{18} \mathrm{~cm}^{-3}$. This indicates that the spectral lines of impurity elements characterize the core dense part of the plasma stream in MPC. In the case when magnetic field is turn off (see Fig. 6,b), it is seen that the density values rather similar, but its spatial behavior differs.

\section{CONCLUSIONS}

Influence of an external magnetic field on the distributions and values of plasma electron density has been studied. A magnetic coil generating an axial magnetic field $0.24 \mathrm{~T}$ has been installed in the MPC accelerating channel to affect the plasma streams dynamics and its parameters.

Obtained spatial distributions of the averageplasma electron density in free plasma stream and in the 
vicinity of the exposed steel target allowsevaluation of the energy density distribution in plasma stream and specific energy load to the target surface during the plasma-surface interaction.

\section{ACKNOWLEDGEMENTS}

This work has been supported in part by National Academy Science of Ukraine projects № П-9/24-2020 and $\Pi-2 / 24-2020$ as well as the Ministry of Education and Science of Ukraine within bilateral PolishUkrainian project.

\section{REFERENCES}

1. R. Kwiatkowski, E. Skladnik-Sadowska, et al. Measurements of electron and ion beams emitted from the PF-1000 device in the upstream and downstream direction // Nukleonika. 2011, v. 56(2), p. 119-123 (in Russian).

2. A.A. Shoshin et al. Plasma-surface interaction during iter type i ELMs: Comparison of Simulation with QSPA Kh-50 and the GOL-3 Facilities // Fusion Science and Technology. 2011, v. 59(1 T), p. 57-60.

3. I.E. Garkusha, V.A. Makhlai, et al. Tungsten melt losses under QSPA Kh-50 plasma exposures simulating ITER ELMS and disruptions // Fusion Science and Technology. 2014, v. 65(2), p. 186-193.

4. S. Pestchanyi, I. Garkusha, I. Landman Simulation of residual thermostress in tungsten after repetitive ELM-like heat loads // Fusion Engineering and Desig. 2011, v. 86(9-11), p. 1681-1684.

5. I.E. Garkusha, O.V. Byrka, V.V. Chebotarev, et al. Properties of modified surface layers of industrial steel samples processed by pulsed plasma streams // Vacuum. 2000, v. 58(2), p. 195-201 (in Russian).

6. A. Marchenko, K. Nowakowska-Langier, et al. // IOP Conf. Series: Journal of Physics: Conf. Series. 2018, v. 959, p. 012006.
7. A. Marchenko et al. // Problems of Atomic Science and Technology. Series «Plasma Physics» (25). 2019, № 1, p. 74-77.

8. V.M. Astashynski, A.H. Sari, S.I. Ananin, et al. Studies on Dynamic Pressure of Compression Plasma Flow // Problems of Atomic Science and Technology. Series «Plasma Physics». 2014, v. 6, p. 157-159.

9. I.P. Dojcinovic, M.M. Kuraica, et. al. Optimization of plasma flow parameters of the magnetoplasma compressor // Pl. Sour. Sci. Techn. 2007, v. 16, p. 72-79.

10. I.E. Garkusha,

T.N. Cherednychenko,

M.S. Ladygina, V.A. Makhlay, et al. // Problems of Atomic Science and Technology. Series «Plasma Physics». 2016, № 6(106), p. 125-128.

11. I.E. Garkusha,

T.N. Cherednychenko,

M.S. Ladygina, V.A. Makhlay, et al. // Physica Scripta. 2014, v. T161, p. 014037.

12. Y.E. Volkova,

D.G. Solyakov,

T.N. Cherednychenko, et al. // Problems of Atomic Science and Technology. Series "Plasma Physics». 2018, № 6, p. 130-133.

13. A. Kozlov // J. Plasma Physics. 2007, v. 74, p. 261-286.

14. D.G. Solyakov,

Y.E. Volkova,

T.N. Cherednychenko, et al. // Problems of Atomic Science and Technology. 2019, № 1, p. 208-211.

15. M. A. Gigosos, S. Djurovi'c, et al. Stark broadening of lines from transition between states $\mathrm{n}=3$ to $\mathrm{n}=2$ in neutral helium // Astronomy and Astrophysics. 2014, v. 561, A135 DOI:10.1051/0004-6361/201322866.

16. M.A. Gigosos, M.Á. González. Stark broadening tables for the helium I 447.1 line // Astronomy and Astrophysics. 2009, v. 503, p. 293-299, DOI: $10.1051 / 0004-6361 / 200912243$

Article received 21.01.2020

\title{
ВЛИЯНИЕ ПРОДОЛЬНОГО МАГНИТНОГО ПОЛЯ В КАНАЛЕ МПК НА ИНТЕГРАЛЬНУЮ ПЛОТНОСТЬ ПЛАЗМЕННОГО ПОТОКА
}

\author{
А.К. Марченко, О.В. Бырка, В.А. Махлай, И.Е. Гаркуша, С.С. Геращенко, \\ Д.Г. Соляков, Ю.Е. Волкова, Д.В. Елисеев, К. Новаковская-Лангер
}

Представлены экспериментальные измерения и анализ параметров плазменных потоков, генерируемых магнитоплазменным компрессором (МПК), который был оснащен внешним магнитным полем. Изучено влияние внешнего магнитного поля 0,24 Тл на потоки гелиевой плазмы (P=2 Торр). Представлены пространственные распределения электронной плотности плазмы как с внешним магнитным полем, так и без него. Распределения электронной плотности плазмы $\mathrm{N}_{\mathrm{e}}(\mathrm{L})$ получены из штарковского уширения спектральных линий $\mathrm{He}$ I и Не II. Также приведены измерения распределений $\mathrm{N}_{\mathrm{e}}(\mathrm{L})$ при налетании плазменного потока МПК на мишень из нержавеющей стали.

\section{ВПЛИВ ПОЗДОВЖНЬОГО МАГНІТНОГО ПОЛЯ В КАНАЛІ МПК НА ІНТЕГРАЛЬНУ ГУСТИНУ ПЛАЗМОВОГО ПОТОКУ}

\section{А.К. Марченко, О.В. Бирка, В.О. Махлай, І.С. Гаркуша, С.С. Геращенко, Д.Г. Соляков, Ю.С. Волкова, Д.В. Слисеєв, К. Новаковська-Лангер}

Представлено експериментальні вимірювання та аналіз параметрів плазмових потоків, що генеруються магнітоплазмовим компресором (МПК), який було оснащено зовнішнім магнітним полем. Вивчено вплив зовнішнього магнітного поля 0,24 Тл на потоки гелієвої плазми ( $\mathrm{P}=2$ Торр). Представлено просторові розподіли електронної густини плазми як із зовнішнім магнітним полем, так і без нього. Розподіли електронної густини плазми $\mathrm{N}_{\mathrm{e}}(\mathrm{L})$ отримано зі штарківського розширення спектральних ліній Не I та Не II. Також представлені вимірювання розподілів $\mathrm{N}_{\mathrm{e}}(\mathrm{L})$ при налітанні пламового потоку МПК на сталеву мішень. 